\title{
Cardiovascular Diseases Healthy Diet Related Knowledge among a Sample of the General Population in Egypt
}

\author{
Marwa M. Zein ${ }^{1}$, Ahmed Taher Mahmoud ${ }^{2 *}$, Ahmed Sallam El Hawary ${ }^{3}$ D , Nelly Hegazy ${ }^{4}$ (D) \\ ${ }^{1}$ Department of Public Health and Community Medicine, Faculty of Medicine, Cairo University, Cairo, Egypt; ${ }^{2}$ Department of \\ Critical Care Medicine, Faculty of Medicine, Cairo University, Cairo, Egypt; ${ }^{3}$ Intern Doctor, Qena Faculty of Medicine, South \\ Valley University, Qena, Egypt; ${ }^{4}$ Department of Public Health and Community Medicine, Faculty of Medicine, Helwan University, \\ Helwan, Egypt
}

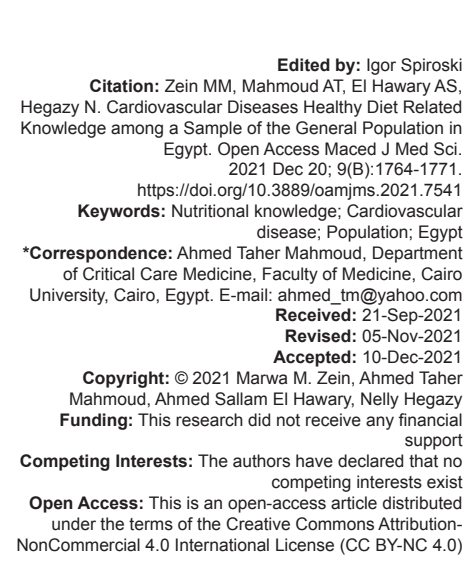

Introduction

Nowadays, non-communicable diseases (NCDs) represent a great challenge, resulting in a global death of 41 million people (71\%) yearly. Low- and middle-income countries are the most affected, with $85 \%$ of premature deaths occurring between 30 and 69 years annually [1]. Cardiovascular diseases (CVDs) are responsible for the most NCDs deaths. Almost one-third of all global deaths in 2019 were attributed to CVDs [2]. NCDs are a critical public health issue in Egypt because they are responsible for $85 \%$ deaths. CVDs, alone, account for $40 \%$ of NCDs' mortality [3].

The risk of NCDs is attributed to modifiable behavioral risk factors, such as unhealthy diet, smoking, physical inactivity, and drinking alcohol. Furthermore, metabolic risk factors, including high blood pressure, obesity, hyperglycemia, and hyperlipidemia, are associated with increasing the risk of NCDs. Hypertension alone is responsible for $19 \%$ of global deaths [4]. The modifiable behavioral risk factors are responsible for $80 \%$ of CVDs, concurrently with the metabolic risk factors, hence increasing the individual's chance to develop CVDs [5].

The STEPS survey of NCDs, which was carried out in 2017 in Egypt, tracked the risk factors for NCDs and revealed the following findings: $35.7 \%$ prevalence of obesity, $8.9 \mathrm{~g} /$ day mean salt intake, $90 \%$ eating $<5$ servings of fruits and vegetables on a daily average, $29.5 \%$ elevated blood pressure, $8.9 \%$ high cholesterol, and $15.5 \%$ high blood glucose [6].

The WHO has spread the public health awareness of diet and physical activity as the "best buy" to overcome the global NCDs increase [7]. Therefore, behavioral modification, as an adoption of a healthy lifestyle, is a crucial strategy to prevent many primary and secondary cardiovascular events. A healthy diet should include vegetables, fruits, nuts, whole grains, lean animal protein, and fish. Moreover, it minimizes the intake of transfats, red meat and processed red meats, refined carbohydrates, and sweetened beverages [8]. 
Rare knowledge is available about the extent of Egyptians' awareness regarding the relationship between nutrition and cardiovascular health. As a result, this study aims to evaluate people's awareness through an online cross-sectional survey.

\section{Designs and Methods}

\section{Study design}

The present study is an exploratory populationbased e-open survey performed by a representative sample to assess their CVDs related knowledge within the study duration from May to August 2021. The research was carried out following the Checklist for Reporting Results of Internet E Surveys guidelines [9].

\section{Sample size and sampling technique}

We used a convenient sampling technique. As there was no prior study focusing on knowledge regarding CVDs, we considered the best assumption (p) as $50 \%$ for the present study. The sample size was calculated using the following formula, (1) $n=\left[\frac{Z_{\alpha / 2}}{E} * P(1-P)\right], n=$ required sample size, $Z_{\alpha / 2}=1.96, p=$ prevalence of the outcome $(50 \%)$, and $E=$ Margin of error; 0.05 . A total of 632 participants completed the questionnaire. The inclusion criterion was to be an adult Egyptian resident ( $\geq 18$ years old).

\section{Data collection tool}

Due to the COVID-19 pandemic, we used an online data collection method. A Google form was created, and the participants were invited to complete and submit it. The questionnaire link was shared with groups on Facebook and WhatsApp. Requests were sent to the administrators of these groups to obtain permission to share the survey. A pre-tested two-page (screen) e-questionnaire was used to collect data from the study participants. It included three sections:

The first section was meant for determining socio-demographic characteristics: Age, sex, education, occupation, marital status, governorate, and selfreported weight and height. The second included a selfreported history of chronic and cardiac diseases. The third evaluated the participants' knowledge regarding CVDs, comprising 15 items addressing dietary risk factors and protective factors. The questions were formatted in a close-ended with "Yes," "No," and "do not know" options.

Different choices, including scientific websites, colleagues, health-care providers, medical studies, television, internet, Facebook, and WhatsApp, were available to determine the sources of knowledge. The questions in this section were adapted from the existing literature [10], [11], [12], [13]. Language experts translated the questions into Arabic. Then, they were translated back to English by two independent language experts.

A pilot test was conducted with ten participants (not included in the study) to assess the clarity of the questions. Furthermore, four faculty members are experts in public health validated the questionnaire's content, and the necessary adjustments were made. The respondents were able to review and change their answers through a back button.

\section{Statistical analysis}

Statistical Package for Social Science version 24.0 was used for statistical analysis [14]. Variables were examined for normality. Categorical variables were expressed in proportions and percentages. Quantitative variables were expressed using mean, standard deviation, median, and interquartile range. Moreover, the Mann-Whitney $U$ and Kruskal-Wallis tests of significance were used for comparison. $P=0.05$ was considered significant. Correct answers received a score of one, while incorrect answers or "I do not know" answers received a score of zero. The total raw score (if all answers were correct) was 15 . The scoring percentage was calculated by dividing the raw score by 15 (the maximum achievable score) and multiplying the result by 100 .

As performed in a previously published study, the scores were divided into tertile (poor, fair, and good) [15]. Knowledge score percentage $<60 \%$ was poor, $60-70 \%$ was fair, and more than $70 \%$ was good.

\section{Ethics approval and consent to participate}

The ethical review board revised and approved the study. Study participants provided electronically signed informed consent. Those who agreed to participate completed the submission process, and those who declined were excluded from the study by submitting an empty form after answering "Not willing to participate." The data confidentially were maintained according to the deceleration of Helsinki.

\section{Results}

Six hundred and thirty-two participants completed the questionnaire. The mean age of them was $28 \pm 8$ years. More than $80 \%$ of the participants were males and had a university education. About $67 \%$ were employed, $35.3 \%$ were married, $70 \%$ were from 
Table 1: Socio-demographic characters of the participants $(n=632)$

\begin{tabular}{|c|c|}
\hline Socio-demographic characteristics & Value \\
\hline Age (years) mean $\pm S D$ & $28 \pm 8$ \\
\hline \multicolumn{2}{|l|}{ Gender $\mathrm{n}(\%)$} \\
\hline Male & $514(81.3)$ \\
\hline Female & $118(18.7)$ \\
\hline \multicolumn{2}{|l|}{ Education n (\%) } \\
\hline University & $506(80.1)$ \\
\hline Below university & $126(19.9)$ \\
\hline \multicolumn{2}{|l|}{ Occupation n (\%) } \\
\hline Working & $423(66.9)$ \\
\hline Not working & $209(33.1)$ \\
\hline \multicolumn{2}{|l|}{ Marital status n (\%) } \\
\hline Married & $223(35.3)$ \\
\hline Not married & $409(64.7)$ \\
\hline \multicolumn{2}{|l|}{ Residence n (\%) } \\
\hline Urban & $443(70.1)$ \\
\hline Rural & $189(29.9)$ \\
\hline \multicolumn{2}{|l|}{ Governorate n (\%) } \\
\hline Greater Cairo & $188(29.7)$ \\
\hline Lower Egypt & $211(33.4)$ \\
\hline Upper Egypt & 207 (32.8) \\
\hline Canal governorates & $26(4.1)$ \\
\hline
\end{tabular}

urban areas, and 66.2\% were from Upper and Lower Egypt (Table 1).

Regarding smoking, 70\% were non-smokers. The body mass index (BMI) of the participants was normal in $35 \%$, while $36.8 \%$ were overweight. Only $10 \%$ suffered from cardiac diseases, mainly hypertension $(76.6 \%)$ (Table 2). The median knowledge percentage score was $62(52,71)$. About $88 \%$ agreed that the diet impacted cardiovascular health, while $51 \%$ were against that drinking coffee being good for heart health.

Table 2: Participants medical history relevant to heart diseases

\begin{tabular}{ll}
\hline Medical History & $\mathrm{n}(\%)$ \\
\hline Smoking status & \\
Yes & $161(25.5)$ \\
No & $442(69.9)$ \\
Ex-smoker & $29(4.6)$ \\
BMI2 & \\
Under-weight (<18.5) & $16(2.5)$ \\
Normal (18.5-24.9) & $221(35.0)$ \\
Overweight (25-29.9) & $232(36.8)$ \\
Class I obesity (30-34.9) & $99(15.7)$ \\
Class II obesity (35-39.9) & $36(5.7)$ \\
Class III obesity (>40) & $27(4.3)$ \\
Chronic diseases & \\
No & $525(83.1)$ \\
Yes & $107(16.9)$ \\
DM & $22(20.6)$ \\
Liver diseases & $2(1.9)$ \\
Kidney diseases & $3(2.8)$ \\
Hyperlipedema & $32(29.9)$ \\
Others & $38(35.5)$ \\
History of cardiac disease & \\
No & $568(89.9)$ \\
Yes & $64(10.1)$ \\
Hypertension & $49(76.6)$ \\
CHD & $8(12.5)$ \\
Valvular diseases & $8(12.5)$ \\
Heart failure & $3(4.7)$ \\
Rheumatic heart & $5(7.8)$ \\
Family history of CVDs & \\
Yes & $119(31.5)$ \\
Do not know & $35(5.5)$ \\
No & $398(63)$ \\
\hline BMl: Body mass index, CVD: Cardiovascular disease, CHD: Coronary heart disease, DM: Diabetes \\
melltos
\end{tabular}

Figure 1 illustrates that more than $75.6 \%$ were often interested in reading the ingredients of a food product to know what they ate. As displayed in Figure 2, 85.4\% of the participants were ready to change their eating habits and follow a healthy diet. Participants demonstrated a poor awareness regarding healthy food for cardiovascular health and how to prepare healthy balanced meals $(71.7 \%$ and $62.2 \%$, respectively), as shown in Figure 3.

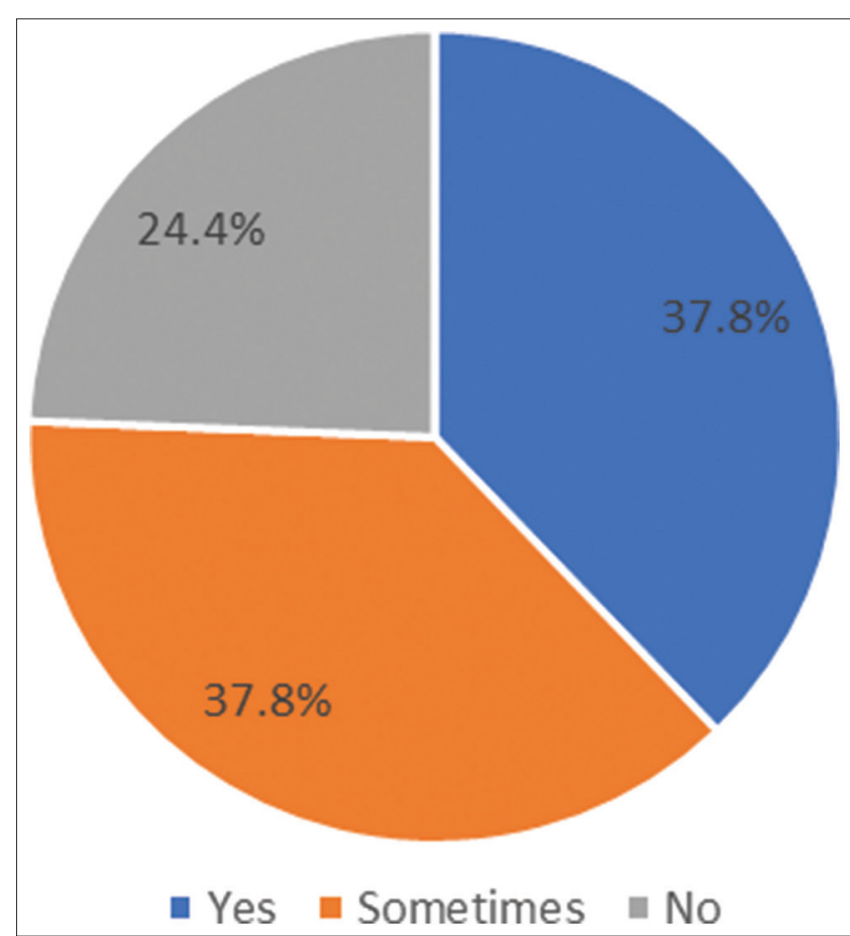

Figure 1: Participants who are interested in reading the ingredients of a food product to know what you are eating

The primary sources of knowledge for the participants were their friends and social media (53.3\% and $40.8 \%$, respectively) as shown in Figure 4. The minor source was the direct search on the internet (2.5\%). As shown in Table 5, females, university educated, employed, and upper Egypt

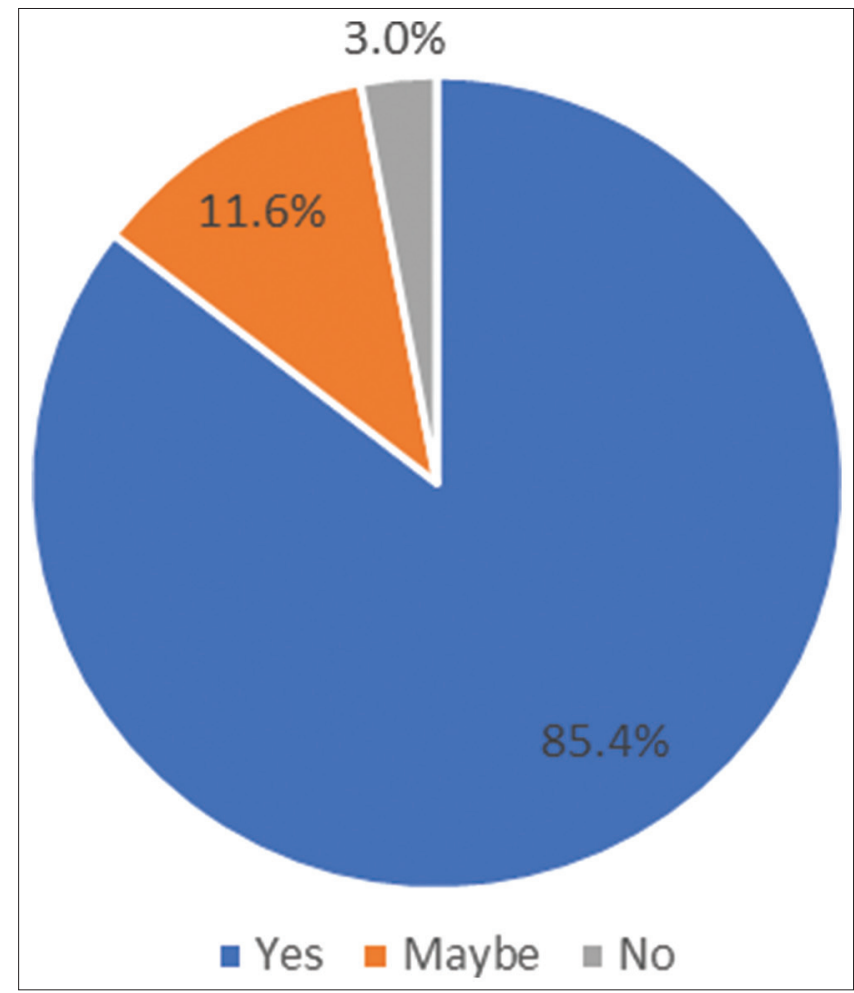

Figure 2: Participants who are ready to change your eating habits and follow a healthy diet to keep your heart healthy 
residents demonstrated increasing awareness ( $p$ $=0.02,0.011,0.05$, and 0.012, respectively). More than one third of the enrolled participants had poor knowledge as shown in Figure 5.

\section{Discussion}

The present study revealed the poor awareness of Egyptians regarding the association between nutrition and cardiovascular health, with a median score of $62(52,71)$. This finding is consistent with Ahmed et al. study, which revealed the poor knowledge of the public Pahang, Malaysia, regarding the modifiable risk factors of a heart attack. However, our findings contradict those revealed from a study on metabolic syndrome patients who demonstrated overall moderate mean knowledge scores of cardiovascular risk factors [15], [16].

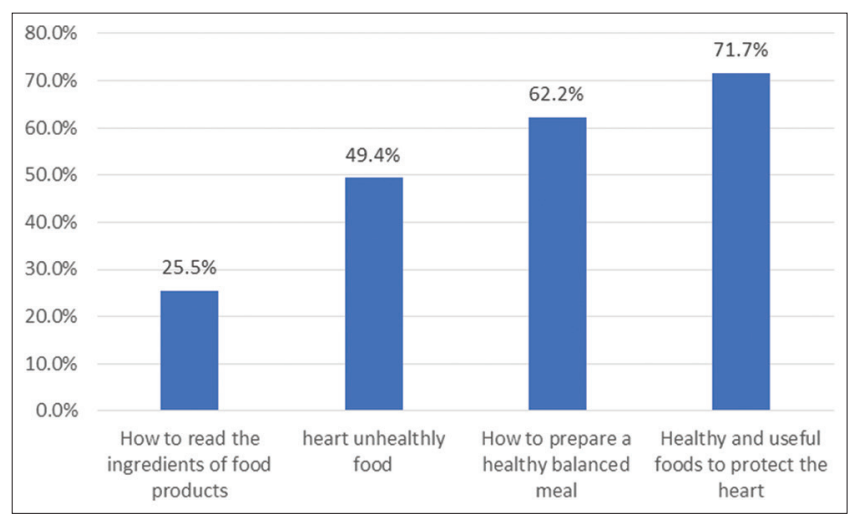

Figure 3: Information which participants like to know more about
Almost all the participants believed in the link between an unhealthy diet and CVDs. Half of the participants agreed that processed meat, such as sausage and hot dogs, could elevate blood cholesterol, negatively affecting cardiovascular health. Nearly twothirds of participants considered eating foods rich in fats and sugars (such as fried pastries and sweets), drinking alcohol, and high salt intake, as harmful for cardiovascular health. Moreover, the association of obesity with heart diseases was well known by $88 \%$ of participants.

On the other hand, it was considered that a diet rich in fibers $(86 \%)$, low fat and fat-free products $(61 \%)$, omega-3 at least twice a week (83\%), and vegetable proteins instead of animal proteins $(72 \%)$ was a preventive measure to reduce the risk of CVDs. Nevertheless, more than half of the participants believed that the high cholesterol levels required medications, with no relation to dietary. Besides, they did not know the different sources of cholesterol in foods and their effects, besides the healthy amount of caffeine.

Amarasekara et al. demonstrated similar results with a higher knowledge score toward high salt consumption and hypertension $90 \%$, but they showed a lower score for vegetables as a positive factor for CVDs reduction [15]. More than two-thirds of participants in the Aminde et al. study reported the unhealthy diet, obesity, and high blood pressure as potential risk factors for CVDs [17].

American studies, conducted among adults aged 18-26 years old and American Indian women with the previous gestational diabetes, showed a high knowledge score for weight reduction $(78.5 \%)$ and emphasized the role of diet and cholesterol on the risk of CVDs. In addition, women in the French West Indies

Table 3: Percent distribution of the enrolled participants by CVD health diet related knowledge $(n=632)$

\begin{tabular}{|c|c|c|c|}
\hline \multirow[t]{2}{*}{ Question } & \multicolumn{3}{|c|}{ Response $\mathrm{n}(\%)$} \\
\hline & Yes & Do not know & No \\
\hline Do you think the only source of cholesterol is animal food products?* & $120(19)$ & $185(29)$ & $327(51)$ \\
\hline 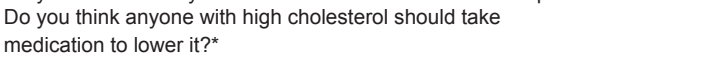 & $230(36)$ & 121 (19) & $281(44)$ \\
\hline Do you think overweight people are more likely to have heart disease? & $557(88)$ & $34(5)$ & $41(6)$ \\
\hline $\begin{array}{l}\text { In your opinion, heart disease has nothing to do with eating foods rich in fats } \\
\text { and sugars (such as fried pastries and sweets)?* }\end{array}$ & $86(13)$ & 79 (12) & $467(73)$ \\
\hline $\begin{array}{l}\text { Do you think that foods rich in natural cholesterol (e.g., eggs/meat/full-fat } \\
\text { dairy products) may lead to an increase in the level of cholesterol in the } \\
\text { blood?* }\end{array}$ & 339 (53) & $114(18)$ & $179(28)$ \\
\hline $\begin{array}{l}\text { Do you think that eating processed meat such as luncheon meat, sausage, } \\
\text { and hot dogs has no effect on cholesterol levels in the blood?*}\end{array}$ & 219 (34) & $101(16)$ & $312(49)$ \\
\hline $\begin{array}{l}\text { Do you think that eating foods rich in salt negatively affects the health of the } \\
\text { heart? }\end{array}$ & $408(64)$ & $129(20)$ & 95 (15) \\
\hline In your opinion, drinking alcohol has nothing to do with heart health?* & $149(23)$ & $126(19)$ & $357(56)$ \\
\hline $\begin{array}{l}\text { In your opinion, is there a significant impact of diet (eating) and the risk of } \\
\text { chronic diseases such as high pressure and heart disease? }\end{array}$ & 566 (89) & $39(6)$ & $27(4)$ \\
\hline $\begin{array}{l}\text { Do you think that following a diet rich in fiber (which comes in whole fruits } \\
\text { with the skin and vegetables such as cucumbers and lettuce) reduces your } \\
\text { chance of developing heart disease? }\end{array}$ & $548(86)$ & $53(8)$ & $31(4)$ \\
\hline $\begin{array}{l}\text { Do you agree that complex carbohydrates, such as those found in whole } \\
\text { wheat and oats, contribute to reducing the risk of heart disease? }\end{array}$ & $360(57)$ & $196(31)$ & $76(12)$ \\
\hline $\begin{array}{l}\text { Do you agree that eating low-fat or fat-free dairy (such as non-fat milk and } \\
\text { yoghurt) is better for heart health and protection than eating full-fat dairy? }\end{array}$ & 390 (61) & 117 (18) & 125 (19) \\
\hline $\begin{array}{l}\text { In your opinion, do you think that eating fish (especially fish rich in omega-3 } \\
\text { such as salmon and sardines) at least twice a week is important for heart } \\
\text { health and protection? }\end{array}$ & $530(83)$ & $76(12)$ & $26(4)$ \\
\hline $\begin{array}{l}\text { In your opinion, is it possible to rely on vegetable proteins (such as lentils, } \\
\text { chickpeas, and peanuts) as an alternative to red meat on some days of the } \\
\text { week? }\end{array}$ & $455(72)$ & 79 (12) & $98(15)$ \\
\hline $\begin{array}{l}\text { In your opinion, drinking coffee and caffeinated drinks (a maximum of } 4 \text { cups/ } \\
\text { day) is good for heart health? }\end{array}$ & 200 (31) & $109(17)$ & $323(51)$ \\
\hline
\end{tabular}


identified eating less fat (42\%) and drinking less alcohol $(26 \%)$ as positive factors for heart health [18], [19], [20].

Table 4: Heart disease dietary risk factors and protective factors knowledge score and knowledge score percent

\begin{tabular}{ll}
\hline Dietary Knowledge & Median (IQR) \\
Score & \\
\hline Knowledge score & $13(11,15)$ \\
Score percent & $62(52,71)$ \\
\hline
\end{tabular}

The studies conducted in Kuwait and the United Arab of Emirates (UAE) displayed high knowledge scores considering the behavioral and metabolic risk factors of CVDs. Unlikely, most elderly living in Bangi demonstrated poor to average knowledge scores toward the dietary risk factors, especially the consequences of eating food rich in salts on blood pressure.

Table 5: Relation between socio-demographics, medical history of the participants, and the knowledge score

\begin{tabular}{|c|c|c|c|c|}
\hline \multirow[t]{2}{*}{ Attributes } & \multicolumn{4}{|l|}{ Knowledge } \\
\hline & Poor n (\%) & Fair n (\%) & Good n (\%) & $p$-value \\
\hline \multicolumn{5}{|l|}{ Age group } \\
\hline$<30$ & $152(37.3)$ & $108(26.5)$ & $147(36.1)$ & \multirow[t]{2}{*}{0.258} \\
\hline$\geq 30$ & $81(36.0)$ & $73(32.4)$ & $71(31.6)$ & \\
\hline \multicolumn{5}{|l|}{ Gender } \\
\hline Male & $206(40.1)$ & $141(27.4)$ & $167(32.5)$ & \multirow[t]{2}{*}{$0.002^{*}$} \\
\hline Female & $27(22.9)$ & $40(33.9)$ & 51 (43.2) & \\
\hline \multicolumn{5}{|l|}{ Education } \\
\hline Read and write & $4(80.0)$ & $1(20.0)$ & $0(0.0)$ & \multirow[t]{6}{*}{$0.011^{*}$} \\
\hline Primary & $0(0.0)$ & $2(50.0)$ & $2(50.0)$ & \\
\hline Preparatory & $4(44.4)$ & $3(33.3)$ & $2(22.2)$ & \\
\hline Secondary & $41(50.6)$ & $15(18.5)$ & $25(30.9)$ & \\
\hline Above intermediate & $10(37.0)$ & $13(48.1)$ & $4(14.8)$ & \\
\hline University & $174(34.4)$ & $147(29.1)$ & $185(36.6)$ & \\
\hline \multicolumn{5}{|l|}{ Occupation } \\
\hline Not working & $91(43.5)$ & $54(25.8)$ & $64(30.6)$ & \multirow[t]{2}{*}{$0.05^{\star}$} \\
\hline Working & $142(33.6)$ & $127(30.0)$ & $154(36.4)$ & \\
\hline \multicolumn{5}{|l|}{ Marital status } \\
\hline Married & $79(35.4)$ & $72(32.3)$ & $72(32.3)$ & \multirow[t]{2}{*}{0.32} \\
\hline Not married & $154(37.7)$ & $109(26.7)$ & $146(35.7)$ & \\
\hline \multicolumn{5}{|l|}{ Residence } \\
\hline Urban & $156(35.2)$ & $130(29.3)$ & $157(35.4)$ & \multirow[t]{2}{*}{0.419} \\
\hline Rural & $77(40.7)$ & $51(27.0)$ & $61(32.3)$ & \\
\hline \multicolumn{5}{|l|}{ Governorate } \\
\hline Greater Cairo & $73(38.8)$ & $64(34.0)$ & $51(27.1)$ & \multirow[t]{4}{*}{$0.012^{\star}$} \\
\hline Lower Egypt & $79(37.4)$ & $63(29.9)$ & $69(32.7)$ & \\
\hline Upper Egypt & $72(34.8)$ & $44(21.3)$ & $91(44.0)$ & \\
\hline Canal governorates & $9(34.6)$ & $10(38.5)$ & 7 (26.9) & \\
\hline \multicolumn{5}{|l|}{ Smoking status } \\
\hline Yes & $71(44.1)$ & $47(29.2)$ & $43(26.7)$ & \multirow[t]{3}{*}{0.084} \\
\hline No & $151(34.2)$ & $124(28.1)$ & $167(37.8)$ & \\
\hline Exsmoker & $11(37.9)$ & $10(34.5)$ & $8(27.6)$ & \\
\hline \multicolumn{5}{|l|}{$\mathrm{BMI}$} \\
\hline$<18.5$ & $5(31.3)$ & $8(50.0)$ & $3(18.8)$ & \multirow[t]{6}{*}{0.148} \\
\hline $18.5-24.9$ & $84(38.0)$ & $58(26.2)$ & $79(35.7)$ & \\
\hline $25-29.9$ & $83(35.8)$ & $62(26.7)$ & 87 (37.5) & \\
\hline $30-34.9$ & $33(33.3)$ & $36(36.4)$ & $30(30.3)$ & \\
\hline $35-39.9$ & $12(33.3)$ & $11(30.6)$ & $13(36.1)$ & \\
\hline$>40$ & $16(59.3)$ & $6(22.2)$ & $5(18.5)$ & \\
\hline \multicolumn{5}{|l|}{ Chronic diseases } \\
\hline No & $191(36.4)$ & $152(29.0)$ & $182(34.7)$ & \multirow[t]{2}{*}{0.847} \\
\hline Yes & $42(39.3)$ & $29(27.1)$ & $36(33.6)$ & \\
\hline \multicolumn{5}{|c|}{ History of cardiac disease } \\
\hline No & $211(37.1)$ & $162(28.5)$ & $195(34.3)$ & \multirow[t]{2}{*}{0.909} \\
\hline Yes & $22(34.4)$ & $19(29.7)$ & $23(35.9)$ & \\
\hline
\end{tabular}

In Malaysia, only half of the participants identified obesity as a risk factor for heart attack [16], [21], [22], [23]. The variation of knowledge scores between countries could be strongly associated with spreading awareness. For example, Kuwait and the UAE governments significantly invest in raising the public's awareness of healthy lifestyles and cardiovascular risk factors. However, other countries, such as Malaysia, have launched many health education initiatives, but they still need effective well-planned awareness campaigns, especially on cardiovascular risk factors [16], [23], [24].

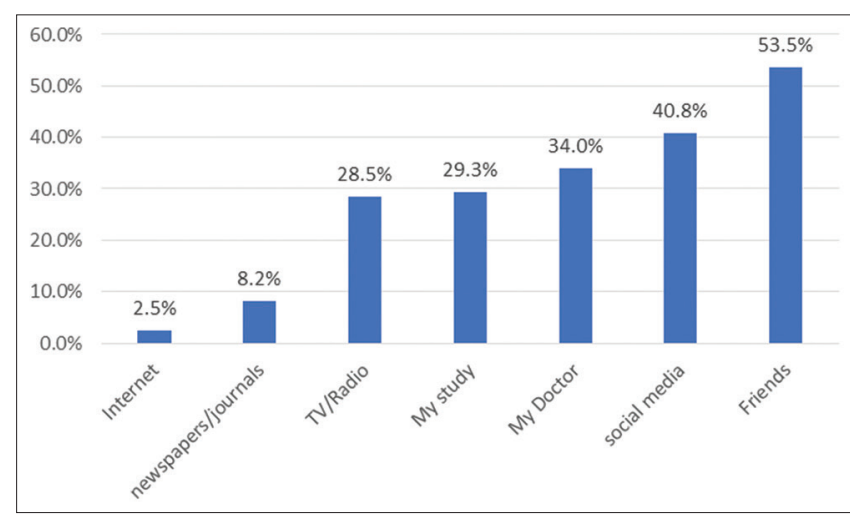

Figure 4: Percent distribution of the studied participants by source of knowledge

Female participants were significantly more knowledgeable than males, and $43.2 \%$ had good knowledge scores. This finding is consistent with similar studies, which demonstrated increasing awareness of females about CVDs risk factors rather than males. In addition, an American study stated that the level of American females' awareness increased by two folds in the past decade [17], [25], [26], [27]. However, males showed higher knowledge scores in a study in Saudi Arabia [28]. Our findings are consistent with the studies emphasizing that females were more aware of asymptomatic and symptomatic CVDs [29]. Inversely, males do not pay much attention to risk factors; they usually believe their health status is better than females [30], [31].

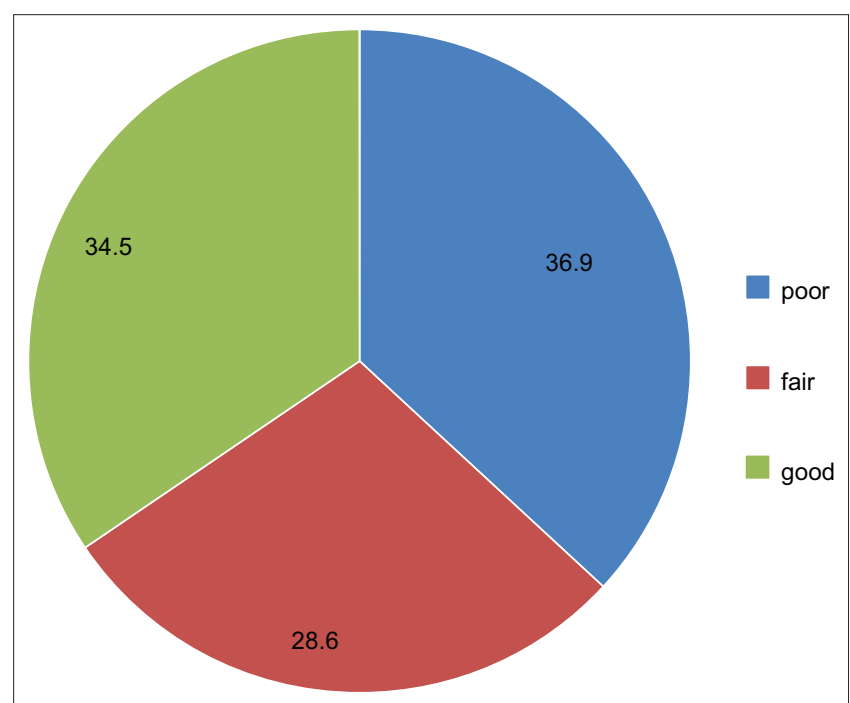

Figure 5: The percent distribution of the overall knowledge score among participants

Highly educated and employed participants demonstrated higher knowledge scores. This finding is consistent with similar studies that revealed an increased awareness of CVDs by increasing education, being employed, and becoming economically stable [17], [32]. This implication can be explained by assuming that highly educated people are more aware and capable of understanding health-related information. 
Besides, participants of Upper Egypt showed higher knowledge scores. This finding could be attributed to their traditions, nutritional habits, climate, working routine, and exposure to different external factors. Unlikely, Lower Egypt has witnessed a strong desire for modernization, reflected in high purchasing power, and accessibility to junk foods [33]. Non-smokers displayed more awareness of CVDs risk factors, as they tried to adopt a healthy lifestyle by avoiding smoking [34]. This finding agrees with a study conducted in Cameroon and disagrees with a Northern Irish study that found no association between smoking and the awareness of CVD risk factors [17], [35].

Regarding the primary sources of nutritional knowledge, $53.5 \%$ of participants stated friends, $40.8 \%$ mentioned social media, and $34 \%$ reported physicians. Consistent with an Italian study, television and physicians were the significant sources of information, with those depending on medical sources demonstrating better awareness of CVDs [36]. Consequently, these findings highlight the need to determine the reliability of the information on social media. In addition, a reliable source for sharing medical information regarding the dietary role in preventing and controlling NCDs must be established.

A healthy diet, as a pivotal factor for cardiovascular health, needs to be emphasized more. It is worth mentioning that $85.5 \%$ of participants desired to change their eating habits in favor of their cardiovascular health. Moreover, more than twothirds were enthusiastic to know the foods enhancing cardiovascular health, besides following healthy balanced meals. Furthermore, one-quarter of the participants showed interest in learning how to read the nutritional labels to figure out the food ingredients. Therefore, physicians should spread nutritional awareness.

\section{Conclusion}

The overall nutritional knowledge of the participants regarding the protective and risk factors for cardiovascular health was poor. Although the majority identified unhealthy diets and obesity as significant risk factors for CVDs, only two-thirds knew the kinds of foods that could negatively affect cardiovascular health. Three-quarters recognized that having food rich in fibers, vegetable proteins, or omega-3 twice/week contributed to protecting from CVDs. Friends and social media were the primary sources of nutritional information. This study highlights the need to raise public awareness to reduce the prevalence of CVDs. The health sectors can collaborate with the medical faculties to conduct health awareness campaigns. The collaboration will guarantee the spread of awareness, on a broader scale, filling the knowledge gaps revealed in the earlier and present studies. Further well-established studies on a broader scale are needed to investigate nutritional behavior.

\section{Study Limitations}

Data were collected through an online questionnaire; therefore, the anthropometric measurement could not be assessed. The BMI was determined using self-reported height and weight. The food quantity and frequency of meals were not determined. Data represent only those who have accessibility to the internet and are familiar with filling online forms.

\section{Acknowledgments}

The authors would like to thank the participants.

\section{Authors Contribution}

All authors have contributed significantly to the content of the manuscript. M.Z. contributed to data analysis and interpretation. A.T. wrote the methodology and revised the discussion and conclusion. A.S. contributed to data collection. N.H. wrote the introduction and discussion. All authors read and approved the final manuscript.

\section{References}

1. World Health Organization. Fact Sheet: Non Communicalble Diseases. Geneva: World Health Organization; 2021. Available from: $\quad$ https://www.who.int/news-room/fact-sheets/detail/ noncommunicable-diseases. [Last accessed on $2021 \mathrm{Feb} 20]$.

2. World Health Organization. Fact Sheet: Cardivascular Diseases (CVDs). Geneva: World Health Organization; 2021. Available from: https://www.who.int/news-room/fact-sheets/detail/ cardiovascular-diseases-(cvds). [Last accessed on 2021 Mar 12].

3. World Health Organization. Egypt: Non Communicable Disease Country Profile. Geneva: World Health Organization; 2018. Available from: https://www.who.int/nmh/countries/egy en.pdf?ua=1. [Last accessed on 2021 Apr 12].

4. Feigin V, Collaborators GR. Global, regional, and national comparative risk assessment of 79 behavioural, environmental and occupational, and metabolic risks or clusters of risks, 19902015: A systematic analysis for the global burden of disease 
study 2015. Lancet. 2016;388(10053):1659-724. https://doi. org/10.1016/S0140-6736(17)32366-8

\section{PMid:28919119}

5. Tran D-MT. College students' perception of current and projected 30 -year cardiovascular disease risk using cluster analysis with internal validation. J Community Health. 2019;44(3):500-6. https://doi.org/10.1007/s10900-018-00609-2

\section{PMid:30554296}

6. World Health Organization. Fact Sheet: Egypt STEPS Survey 2017. Geneva: World Health Organization; 2017. Available from: https://www.who.int/ncds/surveillance/steps/Egypt_ STEPS_Survey_2017_Fact_Sheet.pdf.[Last accessed on 2021 May 25].

7. World Health Organization. Best Buys' and Other Recommended Interventions for the Prevention and Control of Noncommunicable Diseases. Geneva: World Health Organization; 2017.

8. Arnett $D K$, Blumenthal RS, Albert MA, Buroker $A B$, Goldberger ZD, Hahn EJ, et al. 2019 ACC/AHA guideline on the primary prevention of cardiovascular disease: A report of the American College of Cardiology/American Heart Association task force on clinical practice guidelines. J Am Coll Cardiol. 2019;74(10):e177-232. https://doi.org/10.1016/j. jacc.2019.03.010

PMid:30894318

9. Eysenbach G. Improving the quality of web surveys: The checklist for reporting results of internet E-Surveys (CHERRIES). J Med Internet Res. 2004;6(3):e132.

PMid: 15471760

10. Bergman HE, Reeve BB, Moser RP, Scholl S, Klein WM. Development of a comprehensive heart disease knowledge questionnaire. Am J Health Educ. 2011;42(2):74-87. https://doi. org/10.1080/19325037.2011.10599175

PMid:21720571

11. Nalliah CJ, Sanders P, Kalman JM. The impact of diet and lifestyle on atrial fibrillation. Curr Cardiol Rep. 2018;20(12):137. https://doi.org/10.1007/s11886-018-1082-8 PMid:30315401

12. Shrestha M, Pyakurel $P$, Yadav KP, Singh $S$, Priyadarshini $S$, Rajak $\mathrm{B}$, et al. Knowledge, attitude and practices regarding cardiovascular diseases among people of Pakhribas municipalty of Eastern Nepal. Nepalese Heart J. 2020;17(1):33-9.

13. Crea F. The ESC Guidelines on Cardiovascular Prevention and a Focus on Old and New Risk Factors. Oxford, United Kingdom: Oxford University Press; 2021.

14. IBM Corp. IBM SPSS Statistics for Windows, Version 24.0.IBM SPSS Statistics for Windows, Version 24.0. Released. IBM Corp; 2016.

15. Amarasekara $P$, de Silva $A$, Swarnamali $H$, Senarath $U$, Katulanda P. Knowledge, attitudes, and practices on lifestyle and cardiovascular risk factors among metabolic syndrome patients in an urban tertiary care institute in Sri Lanka. Asia Pac J Public Health. 2016;28 Suppl 1:32S-40. https://doi. org/10.1177/1010539515612123

PMid:26512029

16. Ahmed AA, Al-Shami AM, Jamshed S, Zawiah M, Elnaem MH, Ibrahim MI. Awareness of the risk factors for heart attack among the general public in Pahang, Malaysia: A cross-sectional study. Risk Manag Healthc Policy. 2020;13:3089-102. https://doi. org/10.2147/RMHP.S281285 PMid:33380849

17. Aminde LN, Takah N, Ngwasiri C, Noubiap JJ, Tindong M, Dzudie A, et al. Population awareness of cardiovascular disease and its risk factors in Buea, Cameroon. BMC Public Health. 2017;17(1):1-10.
18. Kelly-Irving M, Mulot S, Inamo J, Ruidavets JB, Atallah A, Lang T. Improving stroke prevention in the French West Indies: Limits to lay knowledge of risk factors. Stroke. 2010;41(11):2637-44. https://doi.org/10.1161/STROKEAHA.110.592659 PMid:20884867

19. Winham DM, Jones KM. Knowledge of young African American adults about heart disease: A cross-sectional survey. BMC Public Health. 2011;11(1):248. https://doi. org/10.1186/1471-2458-11-248

\section{PMid:21504588}

20. Jones EJ, Appel SJ, Eaves YD, Moneyham L, Oster RA, Ovalle F. Cardiometabolic risk, knowledge, risk perception, and self-efficacy among American Indian women with previous gestational diabetes. J Obstet Gynecol Neonatal Nurs. 2012;41(2):246-57. https://doi. org/10.1111/j.1552-6909.2012.01339.x PMid:22834848

21. Haron H, Kamal NF, Yahya HM, Shahar S. Knowledge, attitude and practice (KAP) of Malay elderly on salt intake and its relationship with blood pressure. Front Public Health. 2020;8:559071. https://doi.org/10.3389/fpubh.2020.559071 PMid:33614563

22. Khan NS, Shehnaz SI, Guruswami GK, Ibrahim SAM, Mustafa SAJ. Knowledge of warning signs, presenting symptoms and risk factors of coronary heart disease among the population of Dubai and Northern Emirates in UAE: A crosssectional study. Nepal J Epidemiol. 2017;7(2):670-80. https:// doi.org/10.3126/nje.v7i2.17973

PMid:29181228

23. Awad A, Al-Nafisi H. Public knowledge of cardiovascular disease and its risk factors in Kuwait: A cross-sectional survey. BMC Public Health. 2014;14(1):1131. https://doi. org/10.1186/1471-2458-14-1131

PMid:25367768

24. Ministry of Health and Prevention-United Arab Emirates. "Healthy Heart" Campaign: Ministry of Health and PreventionUnited Arab Emirates; 2014. Available from: https://www.mohap. gov.ae/en/mediacenter/news/pages/1346.aspx. [Last accessed on $2021 \mathrm{Jul} 12]$.

25. Güneş FE, Bekiroglu N, Imeryuz N, Agirbasli M. Awareness of cardiovascular risk factors among university students in Turkey. Primary Health Care Res Dev. 2019;20:e127. https:// doi.org/10.1017/S146342361900063X PMid:31477189

26. Christian AH, Rosamond W, White AR, Mosca L. Nine-year trends and racial and ethnic disparities in women's awareness of heart disease and stroke: An American Heart Association national study. J Womens Health. 2007;16(1):68-81. https://doi. org/10.1089/jwh.2006.M072

PMid:17274739

27. Yahia N, Brown CA, Rapley M, Chung M. Level of nutrition knowledge and its association with fat consumption among college students. BMC Public Health. 2016;16(1):1-10.

28. Mujamammi AH, Alluhaymid YM, Alshibani MG, Alotaibi FY, Alzahrani KM, Alotaibi $\mathrm{AB}$, et al. Awareness of cardiovascular disease associated risk factors among Saudis in Riyadh CITY. J Family Med Prim Care. 2020;9(6):3100-5. https://doi. org/10.4103/jfmpc.jfmpc_458_20 PMid:32984180

29. Çengel A. Cardiovascular risk factors in women. Turk Soc Cardiol 2010;38 Suppl 1:17-24

30. Romero D. Cardiovascular Disease Risk and College Students: Do Men and Women Differ? (Gender Differences); 2004.

31. Mosca L, Ferris A, Fabunmi R, Robertson RM. Tracking 
women's awareness of heart disease: An American Heart Association national study. Circulation. 2004;109(5):573-9. https://doi.org/10.1161/01.CIR.0000115222.69428.C9

\section{PMid:14761901}

32. Waśniowska A, Kopeć G, Szafraniec K, Misiowiec W Waligóra $\mathrm{M}$, Brózda $\mathrm{M}$, et al. Assessment of knowledge on cardiovascular disease risk factors by postal survey in residents of Małopolska Voivodeship: Małopolska CArdiovascular PReventive Intervention Study (M-CAPRI). Ann Agric Environ Med. 2017;24(2):201-6. https://doi. org/10.5604/12321966.1228400

PMid:28664694

33. Hassan Wassef H. Food habits of the Egyptians: Newly emerging trends. Eastern Mediterr Health J. 2004;10(6):898-915.

34. Carter BD, Abnet CC, Feskanich D, Freedman ND, Hartge P, Lewis CE, et al. Smoking and mortality beyond established causes. N Engl J Med. 2015;372(7):631-40.

35. Al Hamarneh YN, Crealey GE, McElnay JC. Coronary heart disease: Health knowledge and behaviour. Int J Clin Pharm. 2011;33(1):111-23. https://doi.org/10.1007/s11096-010-9467-9 PMid:21365403

36. Tedesco LMR, Di Giuseppe G, Napolitano F, Angelillo IF. Cardiovascular diseases and women: knowledge, attitudes, and behavior in the general population in Italy. Biomed Res Int. 2015;2015:324692. https://doi.org/10.1155/2015/324692

PMid:25699272 